\title{
Trajectories of rewilding: a taxonomy of wildland management
}

\author{
Holly Deary \\ School of Geography and Sustainable Development, \\ University of St Andrews, \\ Fife KY16 9AL, UK \\ holly.deary@snh.gov.uk \\ Tel: 01463725373 \\ Charles R. Warren * \\ School of Geography and Sustainable Development, \\ University of St Andrews, \\ Fife KY16 9AL, UK \\ crw2@st-andrews.ac.uk \\ Tel: 01334463693
}

* Corresponding author

\begin{abstract}
Rewilding, though a young term, already has numerous meanings. We use Q-methodology to investigate understandings and practices of rewilding amongst managers of wildland on 17 estates in the Scottish uplands. The estates, covering 207,200 ha, include all the main land ownership types in Scotland. All respondents value wildness and biodiversity highly, but the Q-study reveals significant divergence in the interpretations and practices of rewilding, especially concerning (i) the value of naturalness, (ii) the use of management interventions, (iii) the value of cultural heritage and traditional land uses, and (iv) the place of people within wildland. A tripartite taxonomy of wildland management approaches is developed, identifying three 'centres of gravity' along the continuum of viewpoints, emphasising respectively nature's autonomy, active restoration, and the maintainance of wildness within cultural landscapes. The taxonomy provides an analytic framework for evaluating the diverse and often conflicting aspirations for the management of wild places.
\end{abstract}

Key words: Q-methodology; rewilding; Scotland; taxonomy; wildland. 


\section{INTRODUCTION}

Rewilding is a young term, but it has made a rapid journey from the novel fringe to occupy a prominent place in contemporary conservation discourse. This reflects the new-found confidence of the conservation movement as it has become increasingly proactive in its attempts not just to halt but reverse the tide of ecological damage. Rewilding represents a dramatic up-scaling of conservation's vision and ambition in response to the scale and urgency of the biodiversity crisis during the current Sixth Great Extinction (Dirzo et al., 2014). This hopeful, optimistic outlook is encapsulated by Sandom et al. (2013:446): 'rewilding seeks to inspire a generation to set something right and ... [create] a brighter and more sustainable future.' Although the concept only emerged in the 1990s, it already has a complex history and has been invested with numerous meanings (Lorimer et al., 2015). This paper aims to tease apart these meanings, using the Scottish context to shed light on broader international debates.

The seminal definition of rewilding by Soule and Noss (1998:5) - summarised as the 'three Cs' of Cores, Corridors and Carnivores - focuses on 'restoring big wilderness based on the regulatory roles of large predators' in restoring the function and resilience of entire ecosystems through top-down trophic interactions and restored habitat connectivity. The development of the concept by Soulé and Terborgh (1999) advocates continental-scale rewilding including the reintroduction of keystone species, a vision sufficiently bold to be dubbed 'a Marshall Plan for the planet' (Fraser, 2009:14). Boldest of all is E.O. Wilson's (2016) clarion call to hand over half the earth's surface to nature. But since the original coinage of the term, the meanings and practices associated with rewilding have diverged in multiple directions as projects have sprung up around the world (Sandom et al., 2013). The term rapidly acquired broad popular appeal internationally (Fraser, 2009; Balmford, 2012) and 'went viral', not least as a result of tireless championing by popularisers like Monbiot (2013) and the establishment of organisations and networks such as Rewilding Britain and Rewilding Europe (Helmer et al., 2015; Jepson and Schepers, 2016; Meech, 2016).

In the process, as it has been adopted by environmental activists and invested with particular local meanings, the concept has broadened from a defined focus on restoring ecosystem dynamics to encompass 'wilder farming and forestry, educational and healthorientated projects, river restoration, wildlife corridors in cities and programmes for the deeper psychology of relationship to the land, wildness and nature' (Taylor, 2015:22). The North American 'three Cs' conception of rewilding has lost its pre-eminence as the prism of international conservation practice has progressively split the term into a broad spectrum of understandings. In particular, there is significant divergence between rewilding in North America and Europe, both in practical and philosophical terms (Corlett, 2016), resulting in contrasting trans-Atlantic emphases which Hall (2014) characterises respectively as removing culture and injecting nature. In the former, the focus remains the 'three Cs' and trophic rewilding informed by conservation biology, using species reintroductions to restore top-down trophic interactions that promote self-regulating biodiverse systems (Svenning et al., 2016). By contrast, European models are informed by more interdisciplinary conservation science, with prominence given to the rewilding of abandoned and marginal land by passive management of ecological succession and naturalistic grazing (Navarro and Pereira, 2015), a central thread of Rewilding Europe (Jepson, 2016; Tanasecu, 2017). North American rewilding tends to be more interventionist, European more passive, adopting a 'leave it to nature' philosophy (Corlett, 2016).

This divergence of understanding and practice has prompted considerable debate over what rewilding does or should mean (Lorimer et al., 2015). The lack of consensus over definition and practice is illustrated by the contrasting emphases of Sandom et al. (2013) and Seddon 
et al. (2014). This is a live debate, as shown, inter alia, by the exchange between Jørgensen (2015), Prior and Ward (2016) and Cloyd (2016), and by Seddon et al.'s (2014) call for a return to the 'three Cs' conceptualisation as a corrective to what they see as misuses of the term. It seems improbable, however, that this genie can be put back in its original bottle, given the diverse and diverging array of international interpretations. Spatial scales range from local to continental, and temporal reference points from recent history to so-called 'Pleistocene rewilding' (Zimov, 2005; Donlan et al., 2006). Jørgensen (2015:486) argues that the term has now been imbued with such a host of meanings that it has become a 'plastic word', sounding 'imperative and futuristic' yet encompassing so much that 'it lacks specific content'. The strength of the evidence base underpinning rewilding has also been questioned (Fisher and Parfitt, 2016; Nogués-Bravo et al., 2016).

A straightforward reading of the 're' prefix of rewilding implies that an inherent goal is to bring back an earlier, wilder incarnation of nature and enable it to flourish again. Restoring a preanthropogenic 'natural' state is, indeed, a frequent objective. However, because the selection of a single 'Garden of Eden' baseline is unavoidably arbitrary (Breed et al., 2016; Mehrabi, 2016), and may in practice be inappropriate or impossible (Marris, 2011; Balaguer et al., 2014), many choose to frame rewilding as 'wilding', emphasising its future orientation, and focusing on developing ecosystem functions and services (Taylor, 2005; Lorimer, 2015). Thus Seddon et al. (2014:410) argue that the focus should be 'to enhance ecosystem resilience, rather than on restoration to some arbitrary historical state', and Sandom et al. (2013:433) characterise rewilding as 'fundamentally a future-orientated proposal that seeks to learn from the past rather than recreate it'. Tanasecu (2017) also emphasizes rewilding's focus on the future, and argues that the 're' prefix is a distraction from its radical novelty. In response to the plethora of meanings and the emergence of different 'shades' of rewilding with their own labels (e.g. trophic, Pleistocene, passive) (Jepson and Schepers, 2016), both Prior and Ward (2016) and Tanasecu (2017) contend that one central unifying thread shared by many rewilding projects is the goal of enhancing non-human autonomy. Nevertheless, consensus remains elusive. The 'what, when and where' of rewilding - in other words the means and ends, the temporal reference and the spatial scale - are all contested (Deary and Warren, 2017).

The present study focuses on Scotland. Within a UK context, Scotland possesses substantial areas which retain a sense of wildness, ${ }^{1}$ and numerous rewilding initiatives are underway (Mc Morran et al., 2008; Brown et al., 2011; Taylor, 2011). Within a broader international context, however, the 'wild' areas are relatively small, and they all have a history of human use and management stretching back over nine millennia, utilisation which continues today. Visions of big wilderness with the 'three Cs' are therefore of limited relevance because, as Smout (2000:172) puts it, 'in this small, old country ... nothing is wilderness'. In some quarters, this context has fostered a perception that, for environmental and political reasons, rewilding is inapplicable and irrelevant (Brown et al., 2011). This is exacerbated by the fact that 'wildness' has decidedly mixed connotations in the Scottish uplands, unlike its largely positive associations in other parts of Europe and in North America. This jaundiced view is rooted in the cultural trauma of the $19^{\text {th }}$ century Highland Clearances when long-inhabited glens were forcibly 'cleared' of people, creating today's misleading sense of 'unspoiled nature' (Warren, 2009). While the history of many wilderness areas around the world includes the displacement of native peoples, the Highland Clearances have left a particularly acute 'legacy of impotent rage' (Richards, 2000:12) which can generate sharply critical views of rewilding (Mackenzie, 2008). Many people in upland rural communities feel strongly that to apply the label 'wild' to landscapes which generations of their ancestors have worked and called home amounts to the eradication of human history (McMorran et al., 2014). Some therefore regard 'rewilding' as a new form of Clearances, and local people in many 'wild' parts of Scotland would rather see the return of Homo 
sapiens than the reintroduction of carnivores. Similarly, Olwig (2016) characterises rewilding in the English Lake District as a form of virtual enclosure of the commons, while Tanasecu (2017:343) reports the suspicions of local people in Romania's Danube Delta that rewilders wish that they 'would just get out of the way'.

These are charged examples of Jørgensen's (2015) criticism that rewilding discourse frequently separates humans from nature and seeks (explicitly or implicitly) to erase human history by valorising the wild without people. Clearly, then, despite the enthusiasm generated by rewilding, it also generates controversy as its ecological values clash with other values - aesthetic, socio-economic, social justice and environmental preservationist (Prior and Brady, 2017). In such a context in which every landscape is profoundly cultural and rewilding is contested, what can or should rewilding mean? This is not just a question for Scotland but for many environments worldwide, given the widespread acceptance that cultural landscapes are the norm not the exception, even in places long believed to be pristine wildernesses (Marris, 2011; Marris et al., 2013; Lorimer et al., 2015; Pearce, 2015). As Pearce (2016:42) puts it, the onset of the Anthropocene is 'no time for Eden-like myths' because 'however we may love what we think of as 'wild', most of nature is now a mash-up of natural and human-made worlds'. Thus the rewilding of hybrid, multinatural landscapes is a question that has broad international relevance.

The profile of wildness within Scottish conservation and land management policy agendas has risen rapidly, in concert with the growing international importance of ecological restoration within environmental policy (Suding et al., 2015). This is evidenced by the inclusion of rewilding in a 2015 review of protected areas (Pepper et al., 2015) and by the decade-long effort invested in the definition and mapping of wildness (SNH, 2002; Mc Morran et al., 2008; Carver et al., 2012). Notably, the latter led to the formal delineation of Wild Land Areas in 2014, with an official map being published by Scottish Natural Heritage (the government's environment agency) (SNH, 2014). (This postdated the completion of the research reported here.) At present, however, there is no formal policy basis for rewilding in Scotland. Current initiatives have been led by conservation NGOs, individual private landowners and projects on particular reserves rather than any strategic policy. Unsurprisingly, therefore, there is considerable diversity of objectives, approaches, motivations and emphases (Taylor, 2005, 2011; Deary, 2015; Deary and Warren, 2017). Native woodlands, in particular, have a prominent place in many Scottish wildland visions (Wilson, 2015, 2017), as exemplied by the long-term woodland restoration projects at Carrifran Wildwood in the Borders region (Ashmole and Ashmole, 2008) and in Glen Affric in northern Scotland led by Trees for Life (Featherstone, 2004). Many other Scottish rewilding initiatives are described and discussed by Brown et al. (2011) and Taylor (2011), and some of these predate the invention of the term. Indeed, current discussions of rewilding in Scotland have an ancient genealogy, including debates about the value and management of wild places, and about the contrasting perceptions of nature held by locals and outsiders (Smout, 1993, 2000). It is notable that, although the rewilding literature and media coverage gives prominence to animal reintroductions, both internationally and in Scotland (Sandom et al., 2012, 2013; Arts et al. 2014, 2016; Tanasecu, 2017), reintroductions are currently a lower immediate priority than habitat restoration within established Scottish rewilding projects (Deary, 2015).

Rewilding appears in many guises. This study does not attempt to propose a new definition because there is simply too much diversity of practice and vision to be captured by one neat conceptualisation (Gillson, 2015). Instead, by exploring the objectives, priorities and practices of estates managing for wildness enhancement in the Scottish uplands, it identifies discrete positions within the spectrum of interpretations. Specifically, its aims are: 
- To explore areas of commonality and divergence across different interpretations of wildland management and rewilding amongst wildland managers

- To develop a taxonomy of Scottish wildland management approaches

While 'wildland management' and 'rewilding' are not synonymous, they overlap considerably, shading into each other along a contested continuum; the aim here is not to attempt a demarcation but to identify discrete positions along the spectrum and explore how these relate to broader rewilding discourse. The proposed taxonomy aims to move 'wildness' beyond the dualisms within which it can sometimes be framed (wild/artificial, nature/culture) by analysing the multiple understandings of wildness and rewilding which currently co-exist in Scotland and the diverse ways in which these are manifested. The positions identified within this taxonomy are not mutually exclusive or tightly defined; they indicate 'centres of gravity' around which particular perspectives coalesce. The research rationale is in providing an analytic framework for evaluating these diverse and often conflicting conceptual positions and the management frameworks which flow from them.

\section{METHODOLOGY}

The research reported here formed part of a broader project investigating ideas and practices of rewilding, not only in Scotland but internationally (Deary, 2015). Here we focus exclusively on the Scottish context, presenting data gathered in 2011-2013 utilising Qmethodology, a technique which combines quantitative statistical tools of correlation and factor analysis with qualitative principles of contingent meaning and interpretative flexibility (Eden et al., 2005). Q-methodology is adept at revealing relationships between divergent opinions using a small number of variables. It enables the key viewpoints within a group of respondents to be understood holistically and analysed quantitatively (Watts and Stenner, 2012), and allows areas of consensus and contestation to be explored. The method originated in psychology in the 1930s but has long been utilised in environmental science, management and policy research (Addams and Proops, 2000), for example in studies of renewable energy debates (Ellis et al., 2007) and of conservation controversies (Rastogi et al., 2013). Unlike other quantitative approaches, it investigates patterns within perspectives (Barry and Proops, 1999), and is thus ideal for exploring the diversity of viewpoints expressed by wildland managers.

The main steps of Q-methodology are: (1) selecting the P-set, (2) defining the concourse, (3) developing the Q-set, (4) conducting the Q-sort, and (5) statistical analysis. In Q, the study participants are collectively known as the P-set. Participants are chosen for comprehensiveness and diversity rather than representativeness or quantity (Eden et al., 2005). Accordingly, a stakeholder matrix was compiled consisting of 32 Scottish landholdings which met two recruitment criteria: (i) managing wildland (land within the "high wildness' areas of Scotland's relative wildness map (SNH, 2013)), and (ii) engaging proactively in some form(s) of environmental restoration (e.g. promoting natural regeneration, removal of non-native species). The development of the relative wildness map, and the methodology and criteria used, are described by SNH (2017). This mapping was part of the process which, after the completion of this research, led to the formal classification of the Wild Land Areas (SNH, 2014) shown in Figure 1. The process proved controversial because of the sensitivities relating to the Highland Clearances outlined above. Of the 32 upland estates which met the criteria, 17 agreed to participate in an initial Delphi process and in the $Q$ study reported here. The Delphi method is a structured communication technique which distils the anonymous judgements of a panel of experts who, through an iterative procedure, develop their views and reasoning in the light of feedback from each successive round of the process (Hsu and Sandford, 2007; Glass et al., 2013). The Delphi component of the overall project is presented in Deary (2015) and Deary and Warren (2017). 
A sample size of 17 was appropriate for both the Delphi and Q-methodology components, while including landholdings with a range of management objectives, upland environments, geographic location and aspirations. The sample also included all the main ownership types: private (7), NGO (5), community (2), government agency (2) and environmental charity (1). ${ }^{2}$ The landholdings, with an average size of 12,188 ha (range: 650 - 29,500 ha) and covering a total area of 207,200 ha, are located in the central and west Highlands, the Southern Uplands and the Outer Hebrides (Fig. 1). The participants were all professional practitioners involved in upland management. The study recruited estate managers rather than land owners because of their in-depth knowledge and active engagement in practical land management decision-making (not true of all owners), and also due to considerations of availability. The Q-methodology process was initially piloted with six individuals with extensive knowledge of upland management in Scotland, and then undertaken with the P. set.

Having selected the P-set, the next step in the $Q$ method is to compile a wide-ranging collection of statements of relevant viewpoints, termed the concourse. Commonly, the concourse is compiled from literature review, media review and/or participant observation, but in this instance it was derived from in-depth, interactive expert discussions through a Delphi process with the P-set (Deary and Warren, 2017) rendering it current, grounded and relevant to stakeholders. Initially, the Delphi dataset was thematically analysed and coded into categories and sub-categories to identify relevant issues and discourses, producing a set of 150 potential statements. From this, a sub-sample of the concourse - the Q-set was created. We used a structured sampling technique to construct a $Q$-set of 32 concise, neutral statements (Table 1). This process included combining similar statements, and ensuring that the Q-set encompassed the dimensions of wildland management which the Delphi process had revealed as being important (e.g. degrees of intervention; ecological and landscape parameters). Deriving these statements from a Delphi process ensured that the key criteria for developing a well-structured Q-set were met - namely saliency, coverage and balance (Watts and Stenner, 2012). The term 'rewilding' itself was excluded from the Qset. This was to avoid both confusion amongst those unfamiliar with the term and unconscious bias (negative or positive) amongst those with clear views. Instead, the Q-set facilitated a focus on the component parts of rewilding, yielding data from which inferences about rewilding could later be drawn.

The central component of the Q-method then requires each individual within the P-set to arrange the $Q$-set statements into a ranked pattern which best reflects their priorities and values. This produces $\mathrm{Q}$-sorts. Following standard practice, we employed a forced choice frequency distribution comprising a 32-box grid of numbered columns (from +3 to -3 , akin to a Likert spectrum) onto which each participant placed cards on which individual Q-set statements were printed. In a forced choice frequency distribution, the columns in the grid decrease in length towards the extremes. Thus the +3 and -3 columns in the grid each consisted of just two boxes, forcing participants to think hard about their strongest preferences. During and after each sort, participants were invited to elaborate and reflect on the rationale for their chosen pattern, and these conversations were noted or recorded for subsequent qualitative analysis. A strength of the $Q$ method is that people's viewpoints on specific issues are never considered in isolation from other related issues; Q-sorts indicate relative, not absolute, prioritisations (Watts and Stenner, 2012). Thus, even if all statements are regarded as important, a relative ranking still emerges.

The completed $\mathrm{Q}$-sorts provide the basis for the final stage, the $\mathrm{Q}$-factor analysis. This inverts the 'population' and 'variable' relationship of standard factor analysis, correlating Qsorts across the sample of statements, rather than the more usual approach of correlating statements across samples of people (Barry and Proops, 1999). It therefore analyses a 
population of viewpoints rather than a population of people. This reduces the individual Qsorts to a small number of variables - termed 'factors' - by establishing natural groupings of correlated variables which account for much of the variability, using as small a number of factors as possible. By combining quantitative analysis with qualitative interpretation, the $Q$ method provides a way of 'structuring subjectivities' (Eden et al., 2005:413), offering rich and grounded insight into complex problems (Watts and Stenner, 2012). Compared to the usual R-type approach, statistical validity is achieved using a larger number of statements across a smaller number of sorters. The $Q$ analysis enables participants to be grouped by viewpoint based on their correlations with particular factors.

The $17 \mathrm{Q}$-sorts, each encapsulating the viewpoint of the manager of each estate, were analysed using the freeware PQMethod. A correlation matrix for all Q-sorts was produced to identify the degree of (dis)agreeement/(dis)similarity between individual sorts. Centroid factor analysis then revealed elements of common variance (factors). An orthogonal varimax factor rotation was applied to find a parsimonious solution, in this case a three-factor solution. The correlation coefficients or 'loadings' in the rotated factor matrix reveal the extent to which each Q-sort is representative of each factor pattern. Three of the Q-sorts exhibited no statistically significant loading on any factor and so were excluded from the calculation of the normalised factor scores ( $Z$ Scores). These scores identify the statements of greatest and least significance for each factor, thereby establishing the character and perspective on wildland management represented by each factor. Overlaying the metathemes in Table 1 (ecological, landscape, cultural/socio-economic and philosophical) on the $Z$ Scores reveals the thematic emphasis of each factor (Table 2). To characterise each factor fully, the final analytical step is to convert the individual scores for each statement into a single factor array. Factor arrays represent a theoretical 'ideal' Q-sort if a participant had a $100 \%$ loading on that factor (Coogan and Herrington, 2011). These permit 'difference scores' to be calculated, revealing which statements are ranked significantly differently between factors, and those around which there is a measure of consensus (Watts and Stenner, 2012).

\section{RESULTS AND DISCUSSION}

\subsection{A tripartite wildland taxonomy}

The overall objective of this Q-study was to identify the parameters, priorities and relative values which characterise approaches to managing wildland on a selection of Scottish upland estates engaged in restoration practices commonly associated with rewilding.

Although, as expected, the study revealed a continuum of attitudes and motivations, the data permit the identification of three distinct sub-sets within this group of 'rewilding estates'. This then permits the construction of a taxonomy of wildland management which is presented, evidenced and exemplified below. Subsequent sections then explore additional perspectives revealed by the data and reflect on the implications of the taxonomy.

The factor array and difference scores for each factor are presented in Table 3, while Table 4 presents the diagnostic statements which characterise each of the three factors, derived from the Z Scores. From Table 4, the three factors which comprise the taxonomy can be characterised based on the diagnostic statements associated with them. In summary terms, Factor 1 has a strongly ecological flavour, with an emphasis on naturalness, nativeness and experiencing wildness (Q-statements $4,32,11,1$ ), Factor 2 is statistically associated with items linked to sustainable rural economies $(24,20)$, while Factor 3 is distinguishable by its emphasis on authenticity and historical continuity in upland landscapes $(19,29)$, fully embracing the human history of wildland. The following paragraphs detail the characteristics of these three factors. 


\section{Factor 1: Wilderness enhancement - restoring wild nature}

This factor explains $25 \%$ of the study variance, with an eigenvalue of 4.25 . Five of the seven estates which are significantly associated with this perspective are under NGO ownership. The key phrases which encapsulate this outlook are 'natural processes', 'the intrinsic value of nature', and 'the experiential quality of wildness'. The aspiration for wildland is that nature should be autonomous and that the full complement of native species should be present. The intrinsic value of nature is an explicit, distinguishing characteristic (Statement 32 - value: +2 (Table 3)). This philosophical motivation translates into a strong preference for natural processes $(4:+3)$, with the restoration of woodland by natural regeneration preferred to restoration by planting $(2:+2 ; 3:+1)$. Recognising that natural processes are truncated by the absence of keystone species, the reintroduction of extirpated species is supported, though not as an immediate priority $(1:+1)$. The significance of 'natural ecology' emerges strongly in the emphasis on enhancing biodiversity $(5:+3)$ and on maintaining ecological connectivity $(7:+2)$ and functionality $(9:+1)$. The experiential quality of 'wildness' is important $(11:+2)$, and this is seen as being compromised by visual intrusions (13: +1 ; 19 : 1) and traditional land management (17: $-2 ; 18:-3)$. In these 'nature first' landscapes, tourism and recreation are largely accorded low significance $(16:-1 ; 23:-2)$, and socioeconomic sustainability is not on the agenda (20: $-3 ; 24:-2)$. This outlook is well illustrated by the following statement:

"... letting nature decide what to do. In most cases this will take us to a state that existed before man started overexploiting the natural capital - so in many ways it will be going back to the future."

Factor 2: Semi-natural restoration - restoring a natural ecology Explaining $16 \%$ of the overall study variance, and with an eigenvalue of 2.72 , four estates are significantly associated with Factor 2 . These estates are predominantly under private and community ownership. Key phrases for this outlook are 'restoring native woodland', 'ecosystem resilience' and 'sustainability'. The restoration of semi-natural habitats is a key objective, manifested particularly in the desire to restore native woodland, whether through natural regeneration $(2:+3)$ and/or through planting (3: +2$)$. Reintroductions, however, are not a priority $(1:-2)$. Because the emphasis is on a sustainable, natural future $(4:+1 ; 25:+3)$ and on the adaptability of ecosystems in the face of climate change $(9:+1)$, the re-creation of 'authentic', historical landscapes is not part of the vision (8: -2; 29: -2; 30: -3). 'Wildness' as an experiential quality does not resonate strongly (11:0), and so the removal of human artefacts is of no interest (12: -3$)$. While the ecological sustainability of the land is central (5: $+2 ; 7:+2 ; 10:+2)$, a holistic, pragmatic understanding of sustainability $(22:+1)$ means that people have a place in the future of these landscapes $(24:+1)$. Cultural heritage and traditional land uses are regarded largely neutrally, as neither strong detractors nor enhancers of this vision $(17: 0 ; 18 ;-1 ; 19:-1)$. The following is an exemplar statement of this viewpoint:

"We should not seek to hold anything in stasis, or even attempt to recreate past situations. ... Instead, we should look at the positive aspects of our landscapes now, and seek to strengthen and enhance them for maximum ecological and social benefit."

\section{Factor 3: Sustainable land management - restoring the uplands}

Explaining $9 \%$ of the overall study variance, and with an eigenvalue of 1.53 , three estates are significantly associated with Factor 3. Two of these are privately owned and one is in community ownership. Key phrases for this outlook are 'cultural heritage', 'sustainability' and 'natural regeneration'. The vision for wildland focuses on maintaining historical continuity and authenticity (29: +2) while ensuring a sustainable future $(25:+2)$. Therefore, while there is a strong emphasis on biodiversity conservation $(5:+2 ; 10:+2)$ and restoring degraded ecologies $(2:+3)$, ideally by natural means $(3:-3 ; 4:+1 ; 28:+1)$, this should not be 
achieved at the expense of the cultural and traditional heritage $(19:+3)$. Conserving both the natural and cultural heritage is seen as important. Landscape authenticity and perceptual wildness are of some significance $(13:+1)$, but the presence of human artefacts is not regarded as compromising these values (12: -2$)$. The following quotation illustrates this perspective:

“... caring for what we've got; appreciating and understanding through knowledge of the story of how it got to be what it is, and recognising what is valuable in that. ... Looking after that, but also looking forward and accepting the new, and using the best of the old to build the best for the future."

These three factors reflect significant contrasts in management emphases. Nevertheless, it is important to recognise that Q-discourses are not mutually exclusive (Coogan and Herrington, 2011). Each estate loads on a particular factor, but it also has a lesser auxiliary loading on each of the other factors. So although the three factors are distinguisable via their central thrusts and emphases, the perspectives overlap considerably. This is illustrated by the fact that the three estates (two private, one owned by a Trust) which were excluded from the factor arrays do not map onto the three perspectives of this taxonomy; they do not load significantly on any one factor but plot within the conceptual 'middle ground'. Just as biological taxonomies differentiate between closely related sub-species, so this framework identifies 'first cousins' within the rewilding 'family'. Overall, the construction of the taxonomy is at least as significant in revealing commonalities as differences, and these shared goals have greater weight because of the diversity of perspective within the sample. For example, all concur that enhancing wildness should not focus on managing for one particular species or for one narrowly-defined outcome.

\subsection{Characterising and differentiating the three wildland perspectives}

The above taxonomy rests primarily on a statistical differentiation of the three factors. However, as stated above and made clear by Table 3, the perspectives characterised by each factor overlap considerably, as would be expected from the nature of the sample. Given the mix of quantitative and qualitative analysis within $Q$ methodology, it is important to contextualise the statistical findings using the qualitative data from post-sort reflections. Accordingly, in the following discussion, the statistical results are examined in conjunction with statements made by the participants during and after the Q-sort process (presented in italics within double quote marks). This puts 'flesh on the bones' of the statistics, developing the factors into three discourses - viewpoints associated with three linked but distinct profiles of wildland management. The factors thus serve as management profiles.

Three salient features emerge from the analysis of the participants' Q-sorts. Firstly, ecological aspirations for wildland are important within all three factors. Of the five highest $Z$ Scores across the three factors, 11 of the 15 are ecological statements, and there is ubiquitous support for retaining and enhancing biodiversity, especially by increasing woodland cover through natural regeneration. Secondly, there is also general agreement that reviving the land should not be retrospective. Thirdly, promoting a picturesque quality is largely seen as irrelevant, although there were some who regarded particular landscape qualities, such as the absence of human artefacts, as being significant, even though respondents did not generally prioritise aesthetic dimensions of wildland.

Notwithstanding these broad areas of agreement, in detail some subtle but important distinctions emerge. For example, although the ecology of wildland is unanimously championed, ecological resilience and ecological integrity are differentiated. Promoting ecological resilience is a key aspiration for Factor 1's 'wilderness enhancers' (e.g. Statement $4=1.52$ Z Score, Table 2) whereas ecological integrity stands out within Factor 2's emphasis on semi-natural restoration $(2=1.51)$ - "allowing the land to achieve its full 
ecological potential". Factor 2 also emphasises the value of native species in management $(31=0.72)$ and the need for restoration interventions (e.g. tree planting) to regain ecological integrity. For Factor 1 , the focus is less on managing for nativeness $(31=0.002)$ and more on restoring natural processes $(4=1.52)$ - "moving from human domination of ecosystems to one in which natural processes prevail". Thus a distinction emerges between Factor 2's concern with conserving species composition (10 $=0.95$, v. 0.40 for Factor 1$)$ and Factor 1 's emphasis on processes ( $4=1.52$, v. 0.69 for Factor 2$)$.

Several other specific issues which characterize and differentiate the factors merit discussion.

\subsubsection{Cultural heritage and 'tradition'}

Cultural heritage and 'tradition' are highly valued by Factor 3's sustainable land managers (e.g. $29=1.08$ ); failing to be sensitive to the cultural history of today's wildland areas is, in their view, to risk aggravating the wounds of the Highland Clearances. In the words of one participant, ignoring the cultural heritage "is not something which sits comfortably with somebody who has a Highland history". A belief that cultural history can contribute to wildland quality also features in Factor 2 (semi-natural restoration), with one respondent stating that "wildland should never mean the exclusion of people, especially in a landscape with such a rich cultural history". However, support is weaker (e.g. $17=0.12$ ). Moreover, whereas cultural heritage and traditional land uses are valued within Factor 3 as positive contributions to the authenticity and wildness of wildland, with historical features being seen as having "something wild about them", within Factor 2 they are merely accepted as part of a pragmatic vision for integrated land use $(24=0.81)$. For example, "cultural heritage can be a lever for funding" and traditional land management such as crofting can sometimes help to deliver ecological aspirations for wildland. Most negative is Factor 1; human influence is unambiguously regarded as compromising wild quality $(17=-1.43 ; 18=-1.94)$. Thus "there is no place for crofting in wild landscapes" and "wildland is devoid of human influence so how can we incorporate or preserve the cultural landscape?"

\subsubsection{Sustainability and the place of people in wild places}

A similar spectrum of views across the factors applies to the associated question of sustainability and the place of people in wild places. Because of the paramount importance of nature's intrinsic value for Factor 1's 'wilderness enhancers' (32 =1.39), the economic and social sustainability of wildland is not ranked highly $(20=-2.01 ; 24=-1.09)$. Equally, infrastructure for recreation is not welcomed $(16=-0.76 ; 23=-0.91)$, although the value of reconnecting people with the intrinsic value of nature $(26=0.21 ; 27=0.66)$ and the experiential value of wildness $(11=1.08)$ are recognised. By contrast, sustainability is an important part of the wildland vision of both Factors 2 and $3(25=1.53$ and 1.23

respectively), and both also seek to ensure a place for people within wildland, including both tourism and traditional land uses (Factor 2: $17=0.12 ; 20=0.03$; Factor 3: $16=0.20$ ). The inclusion of people is particularly important for Factor 3's sustainable land managers: "Conservation has to be people-orientated. There's no point in having it looking good if there's nobody there to see and enjoy it". It is noteworthy that while both Factors 2 and 3 value sustainability, each emphasises different aspects, with ecological aspects of sustainability uppermost for the former and economic aspects given a higher priority within the latter. So, for example, a semi-natural restoration perspective (Factor 2) is that "we still want the land to be productive in the sense of employment and sporting interests ... but its ecology is at the core", whereas commercial forestry is acceptable within Factor 3's vision because it "can produce an economic surplus, and that allows management of other areas". Such commercially-orientated land uses are, for Factor 3's sustainable land managers, a means of sustaining traditional landscapes and the authenticity of the uplands $(29=1.08)$.

\subsubsection{Historical fidelity, and non-native species}


Finally, two aspects of rewilding which are typically important within rewilding discourses emerge as low priorities in this research. Firstly, achieving historical fidelity is of low significance within all three factors. A desire not to constrain natural process by managing for specified 'end points' means that recreating past conditions is a low priority for the 'wilderness enhancement' viewpoint of Factor $1(8=-0.72 ; 30=-1.2)$; "there is no static end point to aim for". Given the stress on ecological integrity in Factor 2 (semi-natural restoration), it might seem surprising that historical fidelity is even less significant here (8 = $0.87 ; 30=-1.88$ ), but this reflects the belief that, given the dynamism of nature, integrity is about future continuity not recreating the past; "we're concerned with going forwards rather than backwards". Sustainable land managers (Factor 3 ) rank historical fidelity somewhat less negatively $(8=-0.41 ; 30=0.00)$, and this links with the importance of landscape authenticity discussed below. Secondly, and perhaps unexpectedly given the importance attached to naturalness in rewilding discourse, all factors rank the eradication of non-native species at zero. The participants' post-sorting reflections revealed that the neutral positioning of this statement stems from a pragmatic recognition of the futility of fighting the presence of some introduced species. As one commented, "it is so difficult to properly eradicate so many of these types of species, if they're not doing much damage there might be an argument for not doing anything at all'. In this instance, pragmatism trumps idealism.

\subsection{Exploring the implications of the taxonomy}

Many studies have presented descriptive classifications or taxonomies of rewilding (Jørgensen, 2015; Carver, 2016; Corlett, 2016; Nogués-Bravo et al., 2016). Arts et al. (2016), for example, identify three key elements of rewilding as restoring ecological functioning, wilderness experience and natural autonomy, all of which feature prominently in the Q-study results discussed above. The taxonomy presented here descriptively maps the conceptual space occupied by proactive wildland management discourses in the Scottish uplands. Having presented this taxonomy, the focus now shifts to the explanations for and implications of these perceptions and prioritisations. While Mc Morran et al. (2008) classify 'different wilds' as the product of contrasting degrees of wildland quality, this research suggests that these degrees of wildness are themselves conceptualised using distinctly different parameters. Clearly, the particular vision of 'wildland' that is adopted has a strong influence on the management approaches and practices which are deemed appropriate. The use of 'wild' by Factor 1's 'wilderness enhancers' is most akin to international ideas of wilderness in that self-willed nature is a key aspiration, whereas Factor 2 (semi-natural restoration) takes a strongly biophysical wildland viewpoint, focusing on the physical qualities of the land, rather than any philosophical or spiritual value. The following typifies the latter outlook:

I find the whole spiritual wilderness thing a bit contrived. [...] People will take away

from these places what they want to. [...] Our concern is the health of the land." The distinction between these two profiles echoes Aplet et al.'s (2000) differentiation between 'freedom' and 'naturalness' as distinct wilderness attributes, where freedom is the extent to which nature is autonomous and beyond human control (e.g. "freedom in nature"; "natural processes prevail") while naturalness is seen as wholeness relative to historic norms (e.g. "putting all the pieces of the jigsaw back").

\subsubsection{Management interventions within rewilding}

A primary criterion for differentiating between rewilding approaches is the nature and degree of management intervention which is deemed to be acceptable (Lorimer et al., 2015; Corlett, 2016; Nogués-Bravo et al., 2016). This raises the much-discussed dilemma or paradox of intervention (Chapman, 2006: Steinwall, 2015): 'can the road to non-intervention be paved with good interventions?' (Deary and Warren, 2017:217). The degree, purpose and duration of intervention considered appropriate in wildland varies across the three factors, and can be characterised respectively as 1) 'let it be', 2) 'wild by design', and 3) 'sustainable wildland 
management'. In principle, the stance of Factor 1 (wilderness enhancement) is to place faith in nature's ability to restore itself when given autonomy, as in "the earth's ability to heal its own wounds". Short-term interventions to restore truncated natural processes are regarded as justifiable "where the balance has been skewed so long", but generally the intention is to "do the minimum". Even within this purist philosophical position, a degree of pragmatism is evident: "manage nature where it needs it, leave it alone where it doesn't." But the 'let it be' philosophy eschews intervention as far as possible and adopts no pre-determined targets or timeframes, freeing nature to decide the when and what; "whatever results we will accept as a 'result' ". This dovetails with the open-ended approach advocated by Hughes et al. (2011) who argue that, the longer the timeframe adopted for rewilding, the less appropriate it is to be prescriptive about goals, especially in the context of climate change and the emergence of novel ecosystems (Truitt et al., 2015).

Although, in the vernacular, 'wild' is virtually synonymous with 'no human influence', the emphasis on ecological integrity within Factor 2 (semi-natural restoration) de-emphasises this aspect. In fact, in many instances, wildland quality in this sense is maintained by management, and interventions are required for restoration. Given that healing and restoration of the land are important aspirations within both Factors 1 and 2, significant parts of their visions are strongly aligned. The point of divergence is the means rather than the end, and the degree of pragmatism. Estates with a Factor 2 perspective are generally sceptical that a 'let it be' approach will restore a natural ecology within the desired timeframe - or, indeed, ever. In their view, "the history of human impact is too great ... to make nonintervention viable". They seek "the same results, but quicker". For Factor 1 estates, the means for attaining wildness must themselves be wild, whereas for Factor 2 estates the product (in terms of the biophysical quality of the land) is more important than the process. So, for example, Factor 2 estates are willing to use planting to re-establish native woodland whereas natural regeneration is strongly preferred by Factor 1 estates. This echoes the longstanding compositionalist $v$. functionalist dichotomy in conservation (Callicott et al., 1999); rewilding typically prioritises ecological function (Corlett, 2016; Jepson, 2016), especially in the context of the Anthropocene (Lorimer, 2015; Lorimer et al., 2015). Because Factor 2 estates have more clearly defined goals (e.g. species composition), directive management is deemed necessary. There is clearly potential for these discourses to converge in the future as restored processes permit decreasing intervention, but in the Scottish context this is far from imminent: "Perhaps in the future the management intervention can be reduced and withdrawn, but not over the next century."

\subsubsection{The place of people and cultural heritage in wildland}

The different parameters of wild also have significant implications for the place of people within wildland. While all rewilding advocates can agree that past human activities have caused ecological damage, the human role in current and future wilds is recognised as an area of sharp disagreement (Lorimer et al., 2015). This is reflected in our findings. Thus some Factor 1 (wilderness enhancement) estates seek to remove signs of human use most notably modern artefacts - in order to enhance the 'unmodified' quality of wildland, and are comfortable with the word 'wilderness'. By contrast, the discourses of Factor 2 (semi-natural restoration) and Factor 3 (sustainable land management) include human activities - past, present and future - and consciously seek to avoid any association with ideas of wilderness, aware of the negative connotations of the word in the Scottish Highlands and of the well-rehearsed constructivist criticisms of the concept (Cronon, 1996; Castree, 2014; Latour, 2017). Within Factor 3 particularly, wildness exists in relation to, rather than in contradistinction to, people; if there is no one there to experience the wild quality then there is no wildness:

"... a landscape with a long history of management [...] can still be considered 'wild'. After all, what is wildness if not simply an impression upon an observer?" 
Indeed, far from expunging evidence of human presence, the Factor 3 perspective seeks to strengthen the heritage story of these landscapes by encouraging practices which conserve cultural roots. In their view, by conveying meaning and identity, a landscape's history and folklore are important to the authenticity of wildlands, and this creates a desire to celebrate the human history of today's wild landscapes alongside their natural qualities; "naturalised archeological remains ... do add something" and "ruins can actually contribute to that sense of wildness." This concurs with Holdgate's (2003:59) contention that 'culture, custom, poetry and legend are as important as scientific values: nature conservation will only achieve its ends if it goes with the grain of social demand'.

There is also a pragmatic acknowledgement of the revenue-generating potential of both the natural and cultural aspects of wildlands, together with some scepticism that the Factor 1 vision will prove sustainable in the long term. Equally pragmatic is Mc Morran et al.'s (2008) recognition that emphasizing ecological criteria to the exclusion of socio-cultural values is likely to alienate local communities and undermine public support for rewilding. In practice, then, at least within the European context, rewilding often incorporates the idea of economic rejuvenation, thereby daring to imagine 'high civilization living side by side with what could be called high nature (spectacular, wonderful, healthy)' (Tanasecu, 2017:338). This is a vision embraced within Factor 3. In fact, Prior and Brady (2017:37) argue that rewilding can be differentiated from wilderness management precisely on the grounds that it 'does not require human abandonment or erasure of cultural landscapes', while Lorimer (2015:106) suggests similarly that rewilding 'offers a space for wildness without the impossible geography of wilderness'. Factors 2 and 3 dovetail with this perspective, whereas Factor 1 arguably trespasses into 'impossible geography'.

As in any Q-study, it is important to recognise that Q-sorts represent relative, rather than absolute, rankings (Barry and Proops, 1999), and that while landscape quality and experiential wildness score considerably lower in the visions of Factors 2 and 3, this does not mean that such qualities are unimportant for them. Factor 2 estates, with their focus on recreating a natural ecology, do not value cultural heritage as highly as the 'sustainable land managers' of Factor 3 estates do, but they do not regard evidence of historic occupation and cultivation as compromising their idea of wildland quality; "rewilding need in no way involve removing people from the land." Typically, they are comfortable with traditional land uses in wildland, seeing them as contributing to overall sustainability. This outlook echoes the views of respondents in Mc Morran et al.'s (2008:185) study who argued that valuing culture and traditional, low-intensity management is important, not least as a way of countering the criticism that rewilding 'implies land emptied of people' amounting to new Highland Clearances.

\subsubsection{Rewilding trajectories and practical realities}

The above differences of emphasis within an overall rewilding trajectory reiterate the importance of seeing the different visions as segments of a continuum, with considerable overlap, rather than being wholly distinct and separate. This is illustrated in Table 5. Conceptualising rewilding as a trajectory towards greater wildness is advocated by Jepson and Schepers (2016), and also by Carver (2016:3) who writes: 'Whatever flavour rewilding you choose, it can sit somewhere on the human-landscape-ecological modification spectrum as a 'process' that moves us towards a wilder and more natural ecosystem.' Comparisons can be drawn here with the familiar spectra in environmentalism from 'deep' to 'shallow' ecology, and from ecocentric beliefs to more technocentric, interventionist stances. The characteristic underlying values of the three perspectives are summarised in Table 6 , together with illustrative quotations. 
While the individual Q-sorts represent the considered 'mission statement' of the participants, practical management realities often result in divergence from their conceptual position. The Q-sorts therefore represent idealised statements of intent which have to be renegotiated in the context of 'real world' challenges. The following quotation illustrates this:

"I found [the Q-sort] quite revealing in terms of the compromises that are faced by land managers and the contradictions that exist within organisations which are often driven by what can be funded. For instance, you may support removal of human infrastructure but end up building a car park and putting in paths because it is part of a funded project."

In addition to such external drivers, a crucial determinant of which rewilding perspective is adopted on any one estate is the outlook of the owner and her/his professional advisors and managers (Wightman and Higgins, 2000), as well as the legacy of past management. In turn, these influences relate to the type of land ownership, both present and past. This research demonstrates a clear link between ownership type and management objectives. The estates which loaded most heavily on Factor 1 (wilderness enhancement) are predominantly owned by conservation NGOs, Factor 2 (semi-natural restoration) comprises a mix of private and community-owned estates, while the estates comprising Factor 3 (sustainable land management) are predominantly in private ownership. Given that the protection and restoration of nature is often the raison d'être of conservation NGOs and charities, this association is unsurprising. Indeed, the recent expansion of land ownership by conservation organisations in Scotland was partly driven by concerns that private ownership was not delivering environmental protection (Croft, 2004). Equally, it is to be expected that private and community-owned estates demonstrate relatively greater concern for sustainable rural economies, the value of cultural heritage and historical continuity; such estates, even those actively engaged in conservation like those in this sample, typically need to include commercial pursuits. By contrast, the prioritisation of intrinsic natural values by conservation owners, resulting in the marginalisation of social, economic and cultural considerations, has generated criticism, being interpreted in some quarters as misanthropic (Toogood, 2003; Warren, 2009). The Scottish Government's target of increasing the total land area in community ownership to one million acres by 2020 may reinforce the sustainable land management approach at the expense of wilderness enhancement.

The three overlapping, but distinct, wildland trajectories identified through this Q-study can be distinguished via several taxonomic themes, most notably the degree of concern for ecological integrity, the significance of wildness as an experiential quality and the value attached to cultural heritage. The resulting management approaches reflect this divergence, including 'let it be' (placing faith in nature's self-willed autonomy), 'wild by design' (involving active restoration-focused interventions), and 'sustainable wildland management' (maintaining wildness in cultural landscapes). Rewilding is often presented as an attempt to recreate ecosystems from some historic period, but, to adopt the terminology of Peterken (1996), what will inevitably transpire in practice is a new future-natural state (Lorimer et al., 2015). As noted in the introduction, despite its 're' prefix, rewilding is increasingly being framed as a future-orientated pursuit, and this was strongly reflected amongst the respondents in this research, most of whom emphasised the need to be forward-looking. Just one of the estates had explicit aspirations to recreate an ancient ecosystem, whereas the rest regarded the selection of any particular temporal baseline as arbitrary; as one asked, "how far back is wild?" Arguably, rewilding should be informed by both the past and the future (Suding et al., 2015); to quote one of our respondents, it is a case of "going back to the future". 


\section{CONCLUSION: PLURALISM, PURISM AND PRAGMATISM IN REWILDING}

Rewilding means many things to many people. The taxonomy presented here demonstrates that, even amongst a group of Scottish estates which are actively seeking to enhance wildness, priorities and values vary considerably. International interpretations of rewilding are similarly diverse (Gillson, 2015; Corlett, 2016). From a scientific perspective, the term's multivalency and ambiguity is regarded as problematic by some (Fisher and Parfitt, 2016; Nogués-Bravo et al., 2016), but Jørgensen (2015) recognises that its popular appeal owes much to the fact that its vagueness and fuzziness allows people to appropriate it to their own ends. Perhaps, then, its flexibility is its strength (Jepson and Schepers, 2016). Ambiguity can spawn 'creative pluralism', as argued by Reiners and Lockwood (2009), whereas attempts to enforce tight definitions can straitjacket a concept's potential. Notwithstanding its scientific credentials, it has been suggested that 'the rewilding process is very much a matter of the heart' (Taylor, 2011:19), and about rediscovering 'the values of freedom, spontaneity, resilience and wonder' (Jepson and Schepers, 2016:1). This may help to explain why 'rewilding' has caught the popular imagination in a way in which the more scientific 'ecological restoration' never has, thereby endowing it with political potency.

In addressing Jørgensen's (2015:486) critique that rewilding is a 'plastic word', 'signifying everything', Prior and Ward (2016) contend that the objective of enhancing more-thanhuman autonomy unifies the many different versions of rewilding and differentiates it from other restoration practices. Svenning et al. (2016) also argue that a central objective of rewilding is the absence of ongoing human management. While non-intervention or reduced intervention is certainly a widely shared goal, in practice the importance accorded to it varies widely, as shown by the research reported here. Moreover, it can be argued that the very terminology of intervention and non-intervention is inherently flawed because it rests on a conceptual separation of humans and nature which is no longer tenable. In the uncompromising words of Head (2015:318), 'the Anthropocene surely disrupts any lingering notion that we can think of the environmental and social realms as separate and separable'. Marris (2011), Lorimer (2015) and Latour (2017) all develop this line of thinking in perceptive depth, while Seddon et al. (2014) propose that because humans are an integral part of nature, the needs of people must be integrated within rewilding objectives, creating landscapes shared by humans and wildlife. A similar vision is espoused by Prior and Ward (2016:134) who, despite their emphasis on nature's autonomy, envisage future conservation landscapes 'co-habituated and co-shaped by humans and non-humans'. This chimes with the ideas of the 'working wild' (Mackenzie, 2008) and of the 'new wild' in which 'humans are an inescapable part of the landscape' (Pearce, 2015:249). Such thinking directly challenges the more ecocentric, 'wilderness' end of the rewilding spectrum.

Quite apart from such conceptual arguments, there are realpolitik considerations about the delivery of rewilding which raise the ever-present tension between purism and pragmatism. Because rewilding occurs 'in the inhabited and thus political landscapes and ecologies of the Anthropocene' (Lorimer et al., 2015:48), trade-offs are typically required between rewilding ideals and what is socio-politically feasible, often requiring ongoing management. Thus, for example, although Hughes et al. (2011) advocate non-intervention, they recognise that active management which swiftly creates positive, visible landscape changes can be helpful in maintaining the support of stakeholders and the public in order to generate ongoing funding. There is, in fact, widespread pragmatic acknowledgement that while rewilding projects should logically be open-ended, management of some kind will usually be necessary because of societal requirements or spatial constraints (Sandom et al., 2013; Suding et al., 2015; Svenning et al., 2016). More broadly, in a world of profound and ongoing anthropogenic change, management interventions may actually be an unavoidable 
necessity (Corlett, 2016). Thus it will be hard to evade the paradox of managing for wildness - 'the process of using the human touch to erase the human touch' (Hall, 2014:30).

This research makes no judgements about 'good' or 'bad' approaches to enhancing wildness. There are many routes to achieving a 'wilder' place. Given the multi-dimensional nature of 'wildness' (Mc Morran et al., 2008), it is perhaps unsurprising that strategies for enhancing wildland quality are equally multi-faceted, adopting diverse approaches. The framework proposed here offers a means of recognising the positions and aspirations across this spectrum of diversity. Clarity of understanding concerning these 'differing social representations of ecology, tradition and space' (Toogood, 1995:103) may help to resolve some of the tensions associated with conflicting aspirations for the management of wild places. 


\section{NOTES}

1. For descriptions of the characteristics of Scotland's ecosystems, landscapes and management practices, see Warren (2009) and Marrs et al. (2011).

2. For descriptions of the different types of land ownership in the Scottish uplands and discussions of ongoing changes in the context of land reform legislation, see Warren (2009) and Hoffman (2013).

\section{ACKNOWLEDGEMENTS}

The research was funded by the Carnegie Trust for the Universities of Scotland. We would like to express our gratitude to all the respondents for engaging so thoroughly and thoughtfully in the research process. We thank Rob Mc Morran for his constructive comments on an early draft. We are also very grateful to five anonymous referees whose detailed and constructive engagement with the paper enabled us to make significant improvements. 


\section{REFERENCES}

Addams, H. and Proops, J. (eds) 2000. Social Discourse and Environmental Policy: an application of Q-Methodology. Edward Elgar, Cheltenham. 240 pp.

Aplet, G., Thomson, J. and Wilbert, M. 2000. Indicators of wildness: using attributes of the land to assess the context of wilderness. In: McCool, S.F., Cole, D.N., Borrie, W.T., O'Loughin, J. (eds). Wilderness Science in a Time of Change. USDA Forest Service Rocky Mountain Research Station, RMRS 15, Vol. 2: 89-98.

Arts, K., Fischer, A. and Van der Wal, R. 2014. Political decision making, governance shifts and Scottish animal reintroductions: are democratic principles at stake? Journal of Environmental Planning and Management 57(4): 612-628.

Arts, K., Fischer, A. and Van der Wal, R. 2016. Boundaries of the wolf and the wild: a conceptual examination of the relationship between rewilding and animal reintroduction. Restoration Ecology 24(1): 27-34.

Ashmole, M. and Ashmole, P. 2008. The Carrifran Wildwood Story. Borders Forest Trust.

Balaguer, L., Escudero, A., Martin-Duque, J.F., Mola, I. and Aronson, J. 2014. The historical reference in restoration ecology: redefining a cornerstone concept. Biological Conservation 176: 12-20.

Balmford, A. 2012. Wild Hope: on the front lines of conservation success. University of Chicago Press, Chicago. $255 \mathrm{pp}$.

Barry, J. and Proops, J. 1999. Seeking sustainability discourses with Q methodology. Ecological Economics 28: 337-345.

Breed, M.F., Lowe, A.J. and Mortimer, P.E. 2016. Restoration: 'Garden of Eden' unrealistic. Nature 533(7604): 469.

Brown, C., Mc Morran, R. and Price, M.F. 2011. Rewilding - a new paradigm for nature conservation in Scotland? Scottish Geographical Journal 127(4): 288-314.

Carver, S., Comber, A., McMorran, R. and Nutter, S. 2012. A GIS model for mapping spatial patterns and distribution of wild land in Scotland. Landscape and Urban Planning 104 (3-4): 395-409.

Callicott, J.B., Crowder, L.B. and Mumford, K. 1999. Current normative concepts in conservation. Conservation Biology 13(1): 22-35.

Carver, S. 2016. Rewilding ... conservation and conflict. ECOS 37(2): 2-10.

Castree, N. 2014. Making Sense of Nature. Routledge, London. 376 pp.

Chapman, R.L. 2006. Ecological restoration restored. Environmental Values 15: 463-478.

Cloyd, A.A. 2016. Reimagining rewilding: a response to Jørgensen, Prior and Ward.

Geoforum 76: 59-62.

Coogan, J. and Herrington, N. 2011. Q methodology: an overview. Research in Secondary Teacher Education 1(2): 24-28.

Corlett, R.T. 2016. Restoration, reintroduction, and rewilding in a changing world. Trends in Ecology and Evolution 31(6): 453-462.

Croft, T.A. 2004. Conservation charity land ownership in Scotland. Scottish Geographical Journal 20(1-2): 71-82.

Cronon, W., 1996. The trouble with wilderness: or, getting back to the wrong nature. In:

Cronon, W. (ed.). Uncommon Ground: rethinking the human place in nature. Norton \& Co, New York. pp. 69-90. 
Deary, H.A. 2015. 'Visions of wildness': the place or (re)wilding in Scotland's uplands.

Unpublished PhD thesis, University of St Andrews. 385 pp.

Deary, H.A. and Warren, C.R. 2017. Divergent visions of wildness in a storied landscape: exploring rewilding practices and discourses in Scotland's wild places. Journal of Rural Studies 54, in press.

Dirzo, R., Young, H.S., Galetti, M., Cebalos, G., Isaac, N.J.B. and Collen, B. 2014. Defaunation in the Anthropocene. Science 345(6195): 401-406.

Donlan, C.J., Berger, J., Bock, C.E., Bock, J.H., Burney, D.A., Estes, J.A., Foreman, D., Martin, P.S., Roemer, G.W. and Smith, F.A. 2006. Pleistocene rewilding: an optimistic agenda for twenty-first century conservation. American Naturalist 168: 660-681.

Eden, S., Donaldson, A. and Walker, G. 2005. Structuring subjectivities? Using Q methodology in human geography. Area 37(4): 413-422.

Ellis, G., Barry, J. and Robinson, C. 2007. Many ways to say 'no', different ways to say 'yes': applying Q-Methodology to understand public acceptance of wind farm proposals. Journal of Environmental Planning and Management 50(4): 517-551.

Featherstone, A.W. 2004. Rewilding in the north-central Highlands - an update. ECOS 25: 4-10.

Fisher, M. and Parfitt, A. 2016. The challenge of wild nature conserving itself. ECOS 37(3/4): 27-34.

Fraser, C. 2009. Rewilding the World: dispatches from the conservation revolution. Metropolitan Books, New York. 416 pp.

Gillson, L. 2015. Biodiversity Conservation and Environmental Change: using palaeoecology to manage dynamic landscapes in the Anthropocene. Oxford University Press, Oxford. $215 \mathrm{pp}$.

Glass, J., Scott, A.J. and Price, M.F. 2013. The power of process: co-producing a sustainability assessment toolkit for upland estate management in Scotland. Land Use Policy 30(1): 254-265.

Hall, M. 2014. Extracting culture or injecting nature? Rewilding in transatlantic perspective. In: Drenthen, M. and Keulartz, J. (eds), Old World and New World Perspectives in Environmental Philosophy. The International Library of Environmental, Agricultural and Food Ethics 21: 17-35.

Head, L. 2015. The Anthropoceneans. Geographical Research 53(3): 313-320.

Helmer, W., Saavedra, D., Sylven, M. and Schepers, F. 2015. Rewilding Europe: a new strategy for an Old Continent. In: Pereira, H.M. and Navarro, L.M. (eds), Rewilding European Landscapes. Springer, Heidelberg. pp. 171-190.

Hoffman, M. 2013. Why community ownership? Understanding land reform in Scotland.

Land Use Policy 31: 289-297.

Holdgate, M. 2003. The human stake in nature. ECOS 24(1): 57-62.

Hsu, C. and Sandford, B. 2007. The Delphi Technique: making sense of consensus.

Practical Assessment Research and Evaluation 12(10): 1-8.

Hughes, F.M.R., Stroh, P.A., Adams, W.M., Kirby, K.J., Mountford, J.O. and Warrington, S. 2011. Monitoring and evaluating large-scale, 'open-ended' habitat creation projects: a journey rather than a destination. Journal for Nature Conservation 19: 245-253.

Jepson, P. 2016. A rewilding agenda for Europe: creating a network of experimental reserves. Ecography 39: 117-124. 
Jepson, P. and Schepers, F. 2016. Making Space for Rewilding: creating an enabling policy environment. Policy Brief, Rewilding Europe/University of Oxford.

https://www.rewildingeurope.com/wp-content/uploads/2016/05/Making-Space-for-

Rewilding-Policy-Brief1.pdf (accessed 11-7-2017).

Jørgensen, D. 2015. Rethinking rewilding. Geoforum 65: 482-488.

Latour, B. 2017. Facing Gaia: eight lectures on the new climatic regime. Polity Press, Cambridge. 327 pp.

Lorimer, J. 2015. Wildlife in the Anthropocene: Conservation after Nature. Minnesota University Press. $284 \mathrm{pp}$.

Lorimer, J., Sandom, C., Jepson, P., Doughty, C., Barua, M. and Kirby, K.J. 2015.

Rewilding: science, practice and politics. Annual Review of Environment and

Resources 40: 39-62.

Mackenzie, A.F.D. 2008. Undoing Nature: the John Muir Trust's 'Journey for the Wild', the UK, summer 2006. Antipode 40(4): 584-611.

Marris, E. 2011. Rambunctious Garden: saving nature in a post-wild world. Bloomsbury, New York. 210 pp.

Marris, E., Mascaro, J. and Ellis, E.C. 2013. Perspective: is everything a novel ecosystem? If so, do we need the concept? In: Hobbs, R.J., Higgs, E.S. and Hall, C.M. (eds), Novel Ecosystems: intervening in the new ecological world order. Wiley, Chichester. pp. 345-349.

Marrs, S.J., Foster, S., Hendrie, C., Mackey, E.C. and Thompson, D.B.A. (eds) 2011. The Changing Nature of Scotland. The Stationery Office, Edinburgh. 528 pp.

Meech, H. 2016. Wilder vision, wilder lives, wilder nature? Challenges for a new rewilding charity. ECOS 37(2): 19-22.

Mehrabi, Z. 2016. Restoration: avoid arbitrary baselines. Nature 533(7604): 469.

Mc Morran, R., Scott, A.J., and Price, M.F. 2014. Reconstructing sustainability; participant experiences of community land tenure in North West Scotland. Journal of Rural Studies 33: 20-31.

Mc Morran, R., Price, M.F. and Warren, C.R. 2008. The call of different wilds: the importance of definition and perception in protecting and managing Scottish wild landscapes. Journal of Environmental Planning and Management 51(2): 177-199.

Monbiot, G. 2013. Feral: rewilding the land, sea and human life. New York, Penguin. 317 pp.

Navarro, L.M. and Pereira, H.M. 2015. Rewilding abandoned landscapes in Europe. In: Pereira, H.M. and Navarro, L.M. (eds). Rewilding European Landscapes. Springer, Heidelberg. pp. 3-23.

Nogués-Bravo, D., Simberloff, D., Rahbek, C. and Sanders, N.J. 2016. Rewilding is the new Pandora's box in conservation. Current Biology 26: R83-R101.

Olwig, K.R. 2016. Virtual enclosure, ecosystem services, landscape's character and the 'rewilding' of the commons: the 'Lake District' case. Landscape Research 41(2): 253264.

Pearce, F. 2015. The New Wild: why invasive species will be nature's salvation. Icon, London. 310 pp.

Pearce, F. 2016. Catastrophe can set you free. New Scientist 3071: 42-43.

Pepper, S., Benton, T., Park, K., Selman, P., Thomson, J. and Trench, H. 2015. Protected areas for nature - review. Report to Scottish Natural Heritage. 
http://www.snh.gov.uk/docs/A1509577.pdf

Peterken, G. F. 1996. Natural woodland: ecology and conservation in northern temperate Regions. Cambridge University Press. Cambridge. 540 pp.

Prior, J. and Brady, E. 2017. Environmental aesthetics and rewilding. Environmental Values 26(1): 31-51.

Prior, J. and Ward, K.J. 2016. Rethinking rewilding: a response to Jørgensen. Geoforum 69: 132-135.

Rastogi, A., Hickey, G.M., Badola, R. and Hussain, S.A. 2013. Diverging viewpoints on tiger conservation: a Q-method study and survey of conservation professionals in India. Biological Conservation 161: 182-192.

Reiners, W.A. and Lockwood, J.A. 2009. Philosophical Foundations for the Practices of Ecology. Cambridge University Press, Cambridge. 226 pp.

Richards, E. 2000. The Highland Clearances: People, Landlords and Rural Turmoil. Birlinn, Edinburgh. 379 pp.

Sandom, C.J., Bull, J., Canney, S. and Macdonald, D.W. 2012. Exploring the value of wolves (Canis lupus) in landscape-scale fenced reserves for ecological restoration in the Scottish Highlands. In: Somers. M. and Hayward. M (eds), Fencing for Conservation: Restriction of evolutionary potential or a riposte to threatening processes? Springer, New York. pp. 245-276.

Sandom, C., Donlan, C.J, Svenning, J-C. and Hansen, D. 2013. Rewilding. In: Macdonald, D.W. and Willis, K.J. (eds), Key Topics in Conservation Biology 2. Wiley, Chichester. pp. 430-451.

Seddon, P.J., Griffiths, C.J., Soorae, P. and Armstrong, D.P. 2014. Reversing defaunation: restoring species in a changing world. Science 345(6195): 406-412.

Smout, T.C. 1993. The Highlands and the roots of green consciousness, 1750-1990. Scottish Natural Heritage Occasional Papers No. 1. $35 \mathrm{pp}$.

Smout, T.C. 2000. Nature Contested: environmental history in Scotland and northern England since 1600. Edinburgh University Press. 210 pp.

SNH. 2002. Wildness in Scotland's Countryside: a policy statement. Scottish Natural Heritage, Battleby. $23 \mathrm{pp}$.

SNH. 2013. Map of relative wildness throughout Scotland. Scottish Natural Heritage. http://www.snh.gov.uk/docs/A914531.pdf

SNH. 2014. Mapping Scotland's wildness and wild land: a new map of wild land. http://www.snh.gov.uk/protecting-scotlands-nature/looking-after-landscapes/landscapepolicy-and-guidance/wild-land/mapping/ (accessed 15-10-2015).

SNH. 2017. Mapping Wild Land Areas.

http://www.snh.gov.uk/protecting-scotlands-nature/looking-after-landscapes/landscapepolicy-and-guidance/wild-land/mapping/ (accessed 11-7-17).

Soulé, M. and Noss, R. 1998. Rewilding and Biodiversity: complementary goals for continental conservation. Wild Earth, Fall, 22: 1-11.

Soulé, M. and Terborgh, J. (eds) 1999. Continental Conservation: scientific foundations of regional reserve networks. Island Press, Washington DC. 227 pp.

Steinwall, A. 2015. Naturalness or biodiversity: negotiating the dilemma of intervention in Swedish protected area management. Environmental Values 24: 31-54.

Suding, K., Higgs, E., Palmer, M. and 10 others. 2015. Committing to ecological restoration. Science 348(6235): 638-640. 
Svenning, J-C., Pedersen, P.B.M., Donlan, C.J. and 8 others. 2016. Science for a wilder Anthropocene: synthesis and future directions for trophic rewilding research. PNAS 113(4): 898-906.

Tanasecu, M. 2017. Field notes on the meaning of rewilding. Ethics, Policy and Environment 20(3): 333-349.

Taylor, P. 2005. Beyond conservation: a wildland strategy. Earthscan, London. 304 pp.

Taylor, P. (ed.). 2011. Rewilding: ECOS writing on wildland and conservation values.

BANC \& Ethos, Somerset. $491 \mathrm{pp}$.

Taylor, P. 2015. Conservation on its last legs - the prospect for rejuvenation. ECOS 36(2): 22-27.

Toogood, M. 2003. Decolonizing Highland conservation. In: Adams, W.M. and Mulligan, M. (eds) 2003. Decolonizing nature strategies for conservation in a post-colonial era.

Earthscan, London. pp. 152-171.

Truitt, A.M., Granek, E.F., Duveneck, M.J., Goldsmith, K.A., Jordan, M.P. and Yazzie, K.C. 2015. What is novel about novel ecosystems: managing change in an ever-changing world. Environmental Management 55: 1217-1226.

Watts, S. and Stenner, P. 2012. Doing Q Methodological Research: theory, method and interpretation. Sage Publications, London. $238 \mathrm{pp}$.

Warren, C.R. 2009. Managing Scotland's Environment. $2^{\text {nd }}$ Edition. Edinburgh University Press, Edinburgh. 490 pp.

Wightman, A. and Higgins, P. 2000. Sporting estates and the recreational economy in the Highlands and Islands of Scotland. Scottish Affairs 31: 18-36.

Wilson, E.O. 2016. Half-Earth: our planet's fight for life. Liveright, New York. 261 pp.

Wilson, S.McG. 2015. The Native Woodlands of Scotland: ecology, conservation and management. Edinburgh University Press, Edinburgh. 271 pp.

Wilson, S.McG. 2017. The Norwegian land use model: is it right for Scotland? Scottish Forestry 71(1): 26-33.

Zimov, S.A. 2005. Pleistocene Park: return of the mammoth's ecosystem. Science 308(5723): 796-798. 


\section{TABLES}

\begin{tabular}{|c|c|c|}
\hline & Statement & Meta-theme \\
\hline 1. & Reintroduction of extirpated species & $E$ \\
\hline 2. & Restoration of native woodland through natural regeneration & $\mathrm{E}$ \\
\hline 3. & Restoration of native woodland through planting & $\mathrm{E}$ \\
\hline 4. & Promoting natural processes & $\mathrm{E}$ \\
\hline 5. & Retaining or enhancing biodiversity & $E$ \\
\hline 6. & Eradicating non-native species & $\mathrm{E}$ \\
\hline 7. & Establishing ecological connectivity with surrounding land & $\mathrm{E}$ \\
\hline 8. & Using paleoecological indicators (e.g. pollen profiles) in management & $\mathrm{E}$ \\
\hline 9. & Ensuring ecosystems are adaptable in the face of climate change & $E$ \\
\hline 10. & Maintaining high profile species and habitat in favourable condition & $\mathrm{E}$ \\
\hline 11. & Enhancing the sense of wildness from an experiential perspective & L \\
\hline 12. & Removing human artefacts & $\mathrm{L}$ \\
\hline 13. & Ensuring visual intrusions are minimal & $\mathrm{L}$ \\
\hline 14. & Promoting a picturesque quality in the landscape & $\mathrm{L}$ \\
\hline 15. & Providing a sense of adventure for recreationalists & $\mathrm{L}$ \\
\hline 16. & Providing and managing infrastructure for visitor management, e.g. paths & $\mathrm{L}$ \\
\hline 17. & Supporting traditional land management practices such as crofting & C \\
\hline 18. & Providing sporting opportunities, e.g. stalking, grouse shooting & C \\
\hline 19. & Protecting the cultural heritage of the landscape & $\mathrm{C}$ \\
\hline 20. & Ensuring the land is productive & C \\
\hline 21. & Managing for ecosystem services & C \\
\hline 22. & Employing pragmatism in management & $\mathrm{C}$ \\
\hline 23. & Promoting ecotourism and encouraging visitors & $\mathrm{C}$ \\
\hline 24. & Integrated land uses & $\mathrm{C}$ \\
\hline 25. & A sustainable future & C \\
\hline 26. & Environmental education & $\mathrm{C}$ \\
\hline 27. & Fostering more pro-environmental behaviour & C \\
\hline 28. & Enhancing the quality of naturalness & $\mathrm{P}$ \\
\hline 29. & An authentic landscape & $\mathrm{P}$ \\
\hline 30. & Historical accuracy in landscape character & $\mathrm{P}$ \\
\hline 31. & Managing for nativeness & $P$ \\
\hline 32. & The intrinsic value of nature & $\mathrm{P}$ \\
\hline
\end{tabular}

Table 1. The set of 32 statements (the Q-set) used in this Q-methodology study. The metathemes, identified via a Delphi process with the participants (Deary, 2015), are: $E=$ ecological; $L=$ landscape; $C=$ cultural/socio-economic; $P=$ philosophical. 


\begin{tabular}{|c|c|c|c|}
\hline & Statement & $\begin{array}{l}\text { Meta- } \\
\text { theme }\end{array}$ & Z Score \\
\hline \multicolumn{4}{|c|}{ Factor 1} \\
\hline 4. & Promoting natural processes & $\mathrm{E}$ & 1.517 \\
\hline 5. & Retaining or enhancing biodiversity & $\mathrm{E}$ & 1.429 \\
\hline 2. & Restoration of native woodland through natural regeneration & $\mathrm{E}$ & 1.404 \\
\hline 32. & The intrinsic value of nature & $\mathrm{P}$ & 1.393 \\
\hline 7. & Establishing ecological connectivity with surrounding land & $\mathrm{E}$ & 1.304 \\
\hline 11. & Enhancing the sense of wildness from an experiential perspective & $\mathrm{L}$ & 1.079 \\
\hline 28. & Enhancing the quality of 'naturalness' & $\mathrm{P}$ & 0.843 \\
\hline 9. & Ensuring ecosystems are adaptable in the face of climate change & $\mathrm{E}$ & 0.694 \\
\hline \multicolumn{4}{|c|}{ Factor 2} \\
\hline 25. & A sustainable future & $\mathrm{C}$ & 1.525 \\
\hline 2. & Restoration of native woodland through natural regeneration & $\mathrm{E}$ & 1.505 \\
\hline 7. & Establishing ecological connectivity with surrounding land & $\mathrm{E}$ & 1.304 \\
\hline 3. & Restoration of native woodland through planting & $\mathrm{E}$ & 1.326 \\
\hline 5. & Retaining or enhancing biodiversity & $\mathrm{E}$ & 1.429 \\
\hline 10. & Maintaining high profile species and habitat in favourable condition & $\mathrm{E}$ & 0.950 \\
\hline 9. & Ensuring ecosystems are adaptable in the face of climate change & $\mathrm{E}$ & 0.694 \\
\hline 24. & Integrated land uses & $\mathrm{C}$ & 0.805 \\
\hline \multicolumn{4}{|c|}{ Factor 3} \\
\hline 19. & Protecting the cultural heritage of the landscape & C & 1.702 \\
\hline 2. & Restoration of native woodland through natural regeneration & $\mathrm{E}$ & 1.505 \\
\hline 5. & Retaining or enhancing biodiversity & $\mathrm{E}$ & 1.429 \\
\hline 10. & Maintaining high profile species and habitat in favourable condition & $\mathrm{E}$ & 0.950 \\
\hline 25. & A sustainable future & C & 1.230 \\
\hline 29. & An 'authentic' landscape & $\mathrm{P}$ & 1.084 \\
\hline 28. & Enhancing the quality of 'naturalness' & $\mathrm{P}$ & 0.678 \\
\hline 4. & Promoting natural processes & $\mathrm{E}$ & 1.517 \\
\hline
\end{tabular}

Table 2. Upper quartile Z Scores for the three factors, showing the statements from the Qset which contribute most significantly to the management profile of each factor. The meta-theme key is as for Table 1. 


\begin{tabular}{|c|c|c|c|c|}
\hline Abbreviated Q-set statements & $\begin{array}{c}\text { Factor } \\
1\end{array}$ & $\begin{array}{c}\text { Factor } \\
2\end{array}$ & $\begin{array}{c}\text { Factor } \\
3\end{array}$ & $\begin{array}{c}\text { Difference } \\
\text { between highest } \\
\text { and lowest } \\
\text { ranking }\end{array}$ \\
\hline 1. Reintroduction of extirpated species & +1 & -2 & -2 & 3 \\
\hline $\begin{array}{l}\text { 2. Native woodland restoration } \\
\text { (regeneration) * }\end{array}$ & +2 & +2 & -3 & 1 \\
\hline 3. Native woodland restoration (planting) & +1 & +2 & -3 & 5 \\
\hline 4. Promoting natural processes & +3 & +1 & +1 & 2 \\
\hline 5. Retaining or enhancing biodiversity * & +3 & +2 & +2 & 2 \\
\hline 6. Eradicating non-native species * & 0 & 0 & 0 & 0 \\
\hline 7. Ecological connectivity & +2 & +2 & +1 & 1 \\
\hline 8. Using paleoecological indicators * & -1 & -2 & -1 & 1 \\
\hline 9. Ecosystems adaptability re climate change & +1 & +1 & -2 & 3 \\
\hline $\begin{array}{l}\text { 10. Species and habitats in favourable } \\
\text { condition }\end{array}$ & 0 & +2 & +2 & 2 \\
\hline 11. Enhancing the sense of wildness & +2 & 0 & 0 & 2 \\
\hline 12. Removing human artefacts & 0 & -3 & -2 & 3 \\
\hline 13. Minimising visual intrusions & +1 & -1 & +1 & 2 \\
\hline 14. Promoting picturesque landscapes & -1 & 0 & -1 & 1 \\
\hline 15. Providing adventure for recreationalists & -1 & -2 & -3 & 2 \\
\hline 16. Providing infrastructure for visitors & -1 & -1 & 0 & 1 \\
\hline 17. Supporting traditional land management & -2 & 0 & -1 & 2 \\
\hline 18. Providing game sport opportunities & -3 & -1 & 0 & 3 \\
\hline 19. Protecting cultural heritage & -1 & -1 & +3 & 4 \\
\hline 20. Ensuring the land is productive & -3 & 0 & -1 & 3 \\
\hline 21. Managing for ecosystem services * & 0 & 0 & 0 & 0 \\
\hline 22. Employing pragmatism in management & -1 & +1 & 0 & 2 \\
\hline 23. Promoting ecotourism and visitors * & -2 & -1 & -1 & 1 \\
\hline 24. Integrated land uses & -2 & +1 & -2 & 3 \\
\hline 25. A sustainable future & 0 & +3 & +2 & 3 \\
\hline 26. Environmental education * & 0 & 0 & +1 & 0 \\
\hline 27. Fostering pro-environmental behaviour & +1 & 0 & 0 & 1 \\
\hline 28. Enhancing the quality of 'naturalness' & +1 & -1 & +1 & 2 \\
\hline 29. An 'authentic' landscape & 0 & -2 & +2 & 4 \\
\hline 30. Historical accuracy in landscapes & -2 & -3 & 0 & 3 \\
\hline 31. Managing for 'nativeness' & 0 & +1 & +1 & 1 \\
\hline 32. The intrinsic value of nature & +2 & +1 & -1 & 3 \\
\hline
\end{tabular}

Table 3. The factor array for the three factors, and ranking differences. Statements in italics are those with the greatest variance in rankings between each factor, thereby representing the areas of greatest disparity. Statements in bold are those with the greatest consensus, i.e. indistinguishable between any pair of factors. Asterisks indicate statements which are non-distinguishable at $p>0.01$. 


\begin{tabular}{|c|c|c|c|}
\hline Diagnostic statements & \multicolumn{3}{|c|}{ Z scores } \\
\hline Factor 1 & Factor 1 & Factor 2 & Factor 3 \\
\hline 4. Enhancing natural processes & 1.52 & 0.69 & 0.62 \\
\hline 32. Nature's intrinsic value & 1.39 & 0.53 & -0.34 \\
\hline 11. Enhancing experiential sense of wildness & 1.08 & 0.00 & 0.07 \\
\hline 1. Reintroduction of extirpated species & 0.41 & -1.70 & -1.63 \\
\hline 12. Removing human artefacts & 0.39 & -2.08 & -1.09 \\
\hline 25. A sustainable future & 0.18 & 1.53 & 1.23 \\
\hline 29. An authentic landscape & -0.36 & -1.70 & 1.08 \\
\hline 18. Game sport opportunities & -1.94 & -0.19 & 0.01 \\
\hline 20. Land productivity & -2.00 & 0.03 & -0.96 \\
\hline \multicolumn{4}{|l|}{ Factor 2} \\
\hline 24. Integrated land uses & -1.09 & 0.80 & -1.29 \\
\hline 20. Land productivity & -2.00 & 0.03 & -0.96 \\
\hline 13. Minimising visual intrusions & 0.55 & -0.58 & 0.41 \\
\hline 28. Enhancing naturalness & 0.84 & -0.66 & 0.68 \\
\hline 29. An authentic landscape & -0.36 & -1.70 & 1.08 \\
\hline 12. Removing human artefacts & 0.39 & -2.08 & -1.09 \\
\hline \multicolumn{4}{|l|}{ Factor 3} \\
\hline 19. Protecting cultural heritage & -0.07 & -0.26 & 1.70 \\
\hline 29. An authentic landscape & -0.36 & -1.70 & 1.08 \\
\hline 7. Ecological connectivity & 1.30 & 1.41 & 0.34 \\
\hline 30. Historical accuracy in landscape & -1.28 & -1.88 & 0.00 \\
\hline 20. Land productivity & -2.00 & 0.03 & -0.96 \\
\hline 12. Removing human artefacts & 0.39 & -2.08 & -1.09 \\
\hline 9. Adaptibility re climate change & 0.69 & 0.89 & -1.36 \\
\hline 3. Native woodland restoration by planting & 0.63 & 1.33 & -1.84 \\
\hline
\end{tabular}

Table 4. Diagnostic statements characterising each of the three factors, derived from the combined $Z$ scores, utilising only those significant to $p<0.1$. The statements are abbreviated; see Table 1 for full versions. For each Factor, the $Z$ scores of the other two Factors are included for comparative purposes. The percentage of the study variance explained by each Factor is as follows: Factor 1: 25\%; Factor 2: 16\%; Factor 3: 9\%. 


\begin{tabular}{c|c|c|}
$\begin{array}{c}\text { Factor 1 } \\
\text { Restoring wild nature: } \\
\text { nature's autonomy and } \\
\text { experiential wildness }\end{array}$ & $\begin{array}{c}\text { Factor 2 } \\
\text { Restoring a natural ecology: } \\
\text { naturalness and ecological } \\
\text { health }\end{array}$ & $\begin{array}{c}\text { Factor 3 } \\
\text { Restoring the uplands: } \\
\text { authenticity }\end{array}$ \\
\hline & Decreasing significance of 'wildness' \\
\hline & Decreasing purism \\
\hline & Increasing place for cultural heritage \\
\hline & \\
\hline
\end{tabular}

Table 5. Continua of wildland values across the three factors. 


\begin{tabular}{|c|c|c|}
\hline $\begin{array}{c}\text { Factor } 1 \\
\text { Ecocentric perspective }\end{array}$ & $\begin{array}{c}\text { Factor } 2 \\
\text { Soft technocentric } \\
\text { perspective }\end{array}$ & $\begin{array}{c}\text { Factor } 3 \\
\text { Soft anthropocentric } \\
\text { perspective }\end{array}$ \\
\hline $\begin{array}{l}\text { Intrinsic value of nature } \\
\text { “... nature for nature's sake } \\
\text { because nature needs } \\
\text { champions.” }\end{array}$ & $\begin{array}{l}\text { Instrumental view of nature } \\
\text { "Wilderness and wildlife need } \\
\text { economic drivers to push them } \\
\text { up the agenda." }\end{array}$ & $\begin{array}{l}\text { More utilitarian view of nature } \\
\text { "There would be no thought at } \\
\text { all that creating all this wildland } \\
\text { wouldn't create opportunities } \\
\text { for stalkers and sporting } \\
\text { activity of some description." }\end{array}$ \\
\hline $\begin{array}{l}\text { Holistic philosophy of } \\
\text { ecosophy } \\
\text { "We don't want harvesting of } \\
\text { anything because we want the } \\
\text { harvest products to remain in } \\
\text { nature." }\end{array}$ & $\begin{array}{l}\text { Humans as a reference point } \\
\text { of value } \\
\text { "We think it's absolutely critical } \\
\text { that people are out there } \\
\text { experiencing this landscape so } \\
\text { that they buy into its value." }\end{array}$ & $\begin{array}{l}\text { Nature should not trump social } \\
\text { values } \\
\text { "There's no conservation } \\
\text { without community." }\end{array}$ \\
\hline $\begin{array}{l}\text { Minimal human intervention in } \\
\text { nature } \\
\text { "We want to withdraw } \\
\text { management and let nature } \\
\text { take its course." } \\
\text { "Let the chips fall!" }\end{array}$ & $\begin{array}{l}\text { Pragmatism in management } \\
\text { "Grazing is a natural part of the } \\
\text { ecosystem but cattle are easier } \\
\text { to manage and control than } \\
\text { deer are." }\end{array}$ & $\begin{array}{l}\text { Human culture and nature are } \\
\text { complementary } \\
\text { "It shouldn't just be about } \\
\text { conserving the natural } \\
\text { heritage. It should be about the } \\
\text { cultural as well." }\end{array}$ \\
\hline $\begin{array}{l}\text { Alternative, natural approaches } \\
\text { "We have to go on culling deer } \\
\text { for now, but having lynx around } \\
\text { would be better." }\end{array}$ & $\begin{array}{l}\text { Values economic criteria } \\
\text { "It has to be viable. ... We can't } \\
\text { be completely idealistic so we } \\
\text { have to weigh things up." }\end{array}$ & $\begin{array}{l}\text { Wild places as cultural } \\
\text { landscapes } \\
\text { "It's an artificial environment. } \\
\text { Man created it and so now we } \\
\text { have to manage it." }\end{array}$ \\
\hline $\begin{array}{l}\text { People have a debt to nature, } \\
\text { and are not in control } \\
\text { "We owe it to the planet to do } \\
\text { what we can to repair the loss." }\end{array}$ & $\begin{array}{l}\text { Faith in science } \\
\text { "We have really detailed } \\
\text { datasets right across the estate } \\
\text { showing what each soil type } \\
\text { could support in terms of the } \\
\text { NVC classification." }\end{array}$ & \\
\hline $\begin{array}{l}\text { Values emotional, intuitive and } \\
\text { spiritual knowledge } \\
\text { "...the inherent spirit within } \\
\text { nature." }\end{array}$ & $\begin{array}{l}\text { Restoration focussed } \\
\text { "The restoration of critical } \\
\text { ecological processes and } \\
\text { functions is at the core of what }\end{array}$ & \\
\hline
\end{tabular}




\begin{tabular}{|c|c|c|}
\hline & we're doing." & \\
\hline \multicolumn{3}{|l|}{ Criticisms } \\
\hline $\begin{array}{l}\text { Conceptually naive, idealistic } \\
\text { and romantic } \\
\text { "This type of land manager } \\
\text { wants ... to create some } \\
\text { romantic image of the past." }\end{array}$ & $\begin{array}{l}\text { Too deterministic } \\
\text { "I think the likes of [X estate] } \\
\text { are saying we want to 'control' } \\
\text { this." }\end{array}$ & $\begin{array}{l}\text { Trying to be everything to } \\
\text { everything } \\
\text { "I just don't think that [X estate] } \\
\text { are being ambitious enough so } \\
\text { all of their aspirations are } \\
\text { diluted." }\end{array}$ \\
\hline
\end{tabular}

Table 6. The characteristics and values of the three factors, illustrated with quotations from estates representing each perspective. The final row presents criticisms of each factor commonly levelled by those holding the other perspectives. 
Figure 1. Map showing the location of the 17 estates which participated in the research process, all of which lie within areas exhibiting a high degree of relative wildness as mapped by Scottish Natural Heritage (SNH, 2013). Also shown here are Scotland's official Wild Land Areas, finalised after this research was completed. 